\title{
Partners' leisure time truly together upon retirement
}

\author{
Elena Stancanelli ${ }^{1,2^{*}}$ and Arthur Van Soest ${ }^{2,3,4,5}$
}

\author{
* Correspondence: \\ elena.stancanelli@psemail.eu \\ Earlier versions of this study were \\ presented at the annual conference \\ of the Society of Labor Economists \\ in Chicago, the European Society of \\ Population Economics in Aarhus, a \\ workshop on household economics \\ in Nice, a time use conference at \\ INED, and an IZA-RIETI workshop in \\ Tokyo. \\ ${ }^{1}$ Paris School of Economics, CNRS, \\ 106 Boulevard de l'Hopital, 75013 \\ Paris, France \\ ${ }^{2}$ IZA, Bonn, Germany \\ Full list of author information is \\ available at the end of the article
}

\begin{abstract}
Externalities in leisure are considered an important reason for partners' joint retirement. This study quantifies the extent to which partners actually spend more leisure time "together" at retirement. Exploiting legal retirement age in France, we identify the effect of retirement on partners' hours of leisure, distinguishing leisure hours spent together or not. We find that the separate leisure demand of the husband increases dramatically upon his retirement, by about $3 \mathrm{~h}$ per day. The wife's retirement significantly increases both her separate leisure time and the couple's joint leisure time. Because the wife is typically the last to retire, her retirement often coincides with partners' joint retirement. Our findings confirm that leisure complementarities in retirement are significant though perhaps not very large quantitatively.

Jel codes: $C 26, C 31, J 26, J 22$

Keywords: Regression discontinuity, Retirement, Leisure
\end{abstract}

\section{Introduction}

Many retirement studies conclude that an important explanation for the fact that partners retire together are complementarities in leisure, implying that the utility of leisure time increases if leisure is enjoyed together with the partner (Hurd 1990; Gustman and Steinmeier 2000, 2004; Coile 2004; An et al. 2004; Casanova 2010). This is the first study that investigates the extent to which partners actually do spend more leisure time together upon retirement. We exploit diary data collected for both partners on the same day, chosen by the interviewer, to investigate the effect of retirement on partners' leisure hours spent together or separately. To account for the potential endogeneity of partners' retirement decisions, we exploit the legal retirement age in France and instrument retirement with legal retirement age in our model of the demand for leisure.

The economic literature on retirement emphasizes the phenomenon of "joint retirement"-the stylized fact that the two partners in a couple often retire closely after each other, even if they do not have the same age. Joint retirement is explained by institutional arrangements as well as "complementarities in leisure," the fact that leisure activities can be undertaken jointly. In other words, the individual retirement implies a positive externality for the partner's leisure. Earlier studies used this argument in models explaining the retirement decisions of spouses but did not have at hand actual data on partners' leisure activities undertaken together. For example, An et al. (2004)

(C) 2016 Stancanelli and Van Soest. Open Access This article is distributed under the terms of the Creative Commons Attribution 4.0 International License (http://creativecommons.org/licenses/by/4.0/), which permits unrestricted use, distribution, and reproduction in any medium, provided you give appropriate credit to the original author(s) and the source, provide a link to the Creative Commons license, and indicate if changes were made. 
allow for unobserved heterogeneity to capture correlated preferences for leisure (due to "assortative mating") and argue that the remaining correlation in the retirement hazards of the two partners are likely due to complementarities in leisure. None of these studies provide any direct evidence that time spent on joint leisure activities increases upon retirement.

The literature on joint leisure hours of partners to date has focused on dual earners, thus neglecting retirees. Hamermesh $(2000,2002)$ concluded that in the USA, partners adapt their work schedules to be able to enjoy leisure synchronously. In contrast, Hallberg (2003), matching singles to individuals in a couple and using Swedish data, found that "actively" chosen partners' joint leisure was only a small proportion of what happened to be "synchronized" leisure, driven by the working hour schedules prevailing in the society. From the perspective of the individual time allocation decision, Kawaguchi et al. (2013) and Lee et al. (2012) provided compelling evidence of significant increases in individual leisure hours upon legislated changes that reduced working days in Korea and Japan. None of these studies investigated leisure hours of retirees.

Focusing on the individual decision to retire, a large increase in men's housework upon retirement is documented for the USA (Aguiar and Hurst 2005). For France, using a similar approach as the one in this paper, Stancanelli and Van Soest (2012) conclude that although both partners increase housework hours upon retirement, the size of the increase is much larger for the husband than for the wife. These studies did not consider leisure hours.

Here, we model the effect of retirement of partners-referred as the "husband" and the "wife," regardless of whether they are married or cohabiting - on their leisure hours spent together and separately, using diary data. Outstandingly, the response rate to the diary survey was $80 \%$ which makes this dataset very unique. We experiment with four definitions of leisure together. Using the narrowest definition of joint leisure, the husband on average enjoys $5 \mathrm{~h}$ of leisure activities on his own on a typical day, while the wife spends $4 \mathrm{~h}$ of leisure on her own. Over $2.5 \mathrm{~h}$ are spent on leisure activities done together, on average. Adopting the broadest definition of joint leisure, the husband and the wife spend almost 4 and $2.5 \mathrm{~h}$ of leisure separately, respectively, while partners' joint leisure averages to almost $4 \mathrm{~h}$.

To allow for the potential endogeneity of retirement decisions, we exploit legal retirement age in France, which is 60 for many workers. ${ }^{1}$ The diary survey collected information on the day the diary was collected as well as on the month and year of birth of respondents, which enables us to construct approximately continuous measures of age. Because partners were on average more than 2 years apart (and the standard deviation from the mean age difference of partners was over 3 years), we can identify the effect of each partner's being aged 60 on the leisure hours spent separately or together. Joint leisure hours increase significantly upon retirement of the wife ${ }^{2}$-who is usually the last to retire in dual-earner couples. The hours of leisure spent separately by the partners increase significantly upon each partner's retirement and especially so for the husband, for whom the increase is robust to various specification checks. In particular, under all specifications, the increase in joint leisure hours of partners upon retirement is smaller than the increase in the husband's separate leisure hours or housework hours. Therefore, our results confirm that there are significant partners' leisure complementarities in retirement though perhaps less sizable than anticipated in earlier studies. 
The structure of the paper is as follows. The next section presents the econometric model. Section 3 illustrates the data and the sample selection. The results of the estimations are presented in Section 4. Section 5 concludes.

\section{The model}

In the economic literature on labor supply and time allocation, individuals maximize the utility of leisure and consumption, subject to a budget constraint and a time constraint (there are only $24 \mathrm{~h}$ per day). To take into account partners' interactions at the household level, various approaches have been proposed ranging from game theoretic and bargaining models to collective models of the household (see, for example, Pollak 2003; Donni and Moreau 2007, for an account of collective and other household models). In this paper, we take an empirical approach and distinguish three types of leisure time of individuals in a couple: the leisure time spent by each partner separately ( $L_{\mathrm{m}}$ and $L_{\mathrm{f}}$, respectively, for the male (m) and the female (f) partner), which may be seen as partners' private consumption goods, and the leisure hours they spend together $\left(L_{\mathrm{h}}\right)$, which could be seen as a public good. Here, we take a reduced form approach and allow partner's retirement status $\left(R_{\mathrm{m}}\right.$ and $R_{\mathrm{f}}$ respectively, for retirement of the male $(\mathrm{m})$ and the female (f) partner, set equal to one for individuals who have retired from market work and zero otherwise) to affect leisure choices directly. We specify reducedform equations for separate leisure hours and for leisure hours spent together at the time of the survey, which will depend on partners' characteristics $\left(\boldsymbol{Z}_{\dot{v}} i=\mathrm{m}, \mathrm{f}\right)$ and retirement status.

In particular, because partners' preferences for leisure may also determine the timing of retirement, retirement status is potentially endogenous. To allow for this, we take from an instrumental variable approach and exploit the legal retirement age in France, which is 60 years for most workers in the private sector. ${ }^{3}$ Unemployment, maternity, and sick leave periods are fully covered by pension rights, so that interrupted labor market experience will not translate into smaller pension benefits or a longer working life. However, to retire with maximum pension benefits, individuals are also required to have worked for a certain number of years (often 40 years), ${ }^{4}$ which implies that some people may retire after 60 (if they entered the labor market later). Other people may retire earlier than 60-due to special early retirement schemes or specific employment sector rules. This implies that it is possible to use a dummy for having reached age 60 as an instrument for retirement, to estimate the effect of retirement on leisure hours (indeed, keeping retirement constant, leisure hours change only continuously with age). There are no other policies in France that affect individuals reaching age 60. In our data, retirement is measured at the time of the interview and we know the exact day, month, and year of the interview. Our setup is bivariate: the retirement dummies of both partners are potentially endogenous regressors in the joint and separate leisure equations. Therefore, we create two instruments for these two potentially endogenous regressors. Because we allow for (unrestricted) correlations among the spouses' leisure and retirement decisions (see below), our approach differs from a regression discontinuity approach.

Here, we estimate a joint model for leisure hours together $\left(L_{\mathrm{h}}\right)$, separate leisure hours of the husband $\left(L_{\mathrm{m}}\right)$, and separate leisure hours of the wife $\left(L_{\mathrm{f}}\right)$, using four alternative definitions of leisure "together" (see Section 3). ${ }^{5}$ To account for the endogeneity of 
retirement in the leisure equations, we also specify two equations for the two retirement dummies $R_{\mathrm{m}}$ and $R_{\mathrm{f}}{ }^{6}$ giving the following simultaneous five-equation model:

1) $L_{\mathrm{m}}=\alpha_{\mathrm{m}}+R_{\mathrm{m}} \iota_{\mathrm{m}}{ }^{\mathrm{m}}+R_{\mathrm{f}} \iota_{\mathrm{m}}{ }^{\mathrm{f}}+\mathbf{A g \mathbf { e } _ { \mathbf { m } }} \boldsymbol{\pi}^{\mathbf{m m}}+D_{\mathrm{m}} \mathbf{A g \mathbf { e } _ { \mathbf { m } }} \boldsymbol{\eta}^{\mathbf{m m}}+\mathbf{A g e}_{\mathbf{f}} \boldsymbol{\pi}^{\mathbf{m f}}$

$+D_{\mathrm{f}} \mathbf{A g e}_{\mathbf{f}} \boldsymbol{\eta}^{\mathbf{m f}}+\boldsymbol{Z}_{\mathrm{m}} \beta^{\mathbf{m m}}+\boldsymbol{Z}_{\mathrm{f}} \beta^{\mathbf{m f}}+v_{\mathrm{m}}$

2) $L_{\mathrm{f}}=\alpha_{\mathrm{f}}+R_{\mathrm{m}} \iota_{\mathrm{f}}^{\mathrm{m}}+R_{\mathrm{f}} \iota_{\mathrm{f}}^{\mathrm{f}}+\mathbf{A g e}_{\mathbf{m}} \mathbf{\pi}^{\mathrm{fm}}+D_{\mathrm{m}} \mathbf{A g e} \mathbf{m}_{\mathrm{m}} \eta^{\mathrm{fm}}+\mathbf{A g e}_{\mathbf{f}} \mathbf{\pi}^{\mathrm{ff}}+D_{\mathrm{f}} \mathbf{A g e}_{\mathrm{f}} \eta^{\mathrm{ff}}$ $+Z_{\mathrm{m}} \beta^{\mathrm{fm}}+Z_{\mathrm{f}} \beta^{\mathrm{ff}}+v_{\mathrm{f}}$

3) $L_{\mathrm{h}}=\alpha+R_{\mathrm{m}} \iota^{\mathrm{m}}+R_{\mathrm{f}} \iota^{\mathrm{f}}+\mathbf{A g e}_{\mathbf{m}} \boldsymbol{\pi}^{\mathbf{m}}+D_{\mathrm{m}} \mathbf{A g e} \mathbf{e}_{\mathbf{m}} \eta^{\mathbf{m}}+\mathbf{A g e}_{\mathbf{f}} \boldsymbol{\pi}^{\mathbf{f}}+D_{\mathrm{f}} \mathbf{A g e}_{\mathbf{f}} \eta^{\mathbf{f}}+Z_{\mathrm{m}} \beta^{\mathbf{m}}$ $+\boldsymbol{Z}_{\mathrm{f}} \beta^{\mathrm{f}}+v_{\mathrm{h}}$

4) $\mathrm{R}_{\mathrm{m}}=\alpha^{\mathrm{rm}}+D_{\mathrm{m}} \gamma^{\mathrm{rmm}}+D_{\mathrm{f}} \gamma^{\mathrm{rmf}}+\mathbf{A g e}_{\mathbf{m}} \mathbf{\pi}^{\mathbf{r m m}}+D_{\mathrm{m}} \mathbf{A g e} \mathbf{e}_{\mathbf{m}} \eta^{\mathbf{r m m}}+\mathbf{A g e}_{\mathbf{f}} \boldsymbol{\pi}^{\mathbf{r f m}}$ $+D_{\mathrm{f}} \mathbf{A g e}_{\mathbf{f}} \eta^{\mathrm{rfm}}+Z_{\mathrm{m}} \beta^{\mathrm{rmm}}+Z_{\mathrm{f}} \beta^{\mathrm{rfm}}+v^{\mathrm{rm}}$

5) $\mathrm{R}_{\mathrm{f}}=\alpha^{\mathrm{rf}}+D_{\mathrm{m}} \gamma^{\mathrm{rfm}}+D_{\mathrm{f}} \gamma^{\mathrm{rff}}+\mathbf{A g e}_{\mathbf{m}} \mathbf{\pi}^{\mathrm{rfm}}+D_{\mathrm{m}} \mathbf{A} \mathbf{g e} \mathbf{e}_{\mathbf{m}} \eta^{\mathrm{rfm}}+\mathbf{A g e}_{\mathbf{f}} \pi^{\mathbf{r f f}}$ $+D_{\mathrm{f}} \mathbf{A g e}_{\mathbf{f}} \eta^{\mathrm{rff}}+Z_{\mathrm{m}} \beta^{\mathrm{rfm}}+Z_{\mathrm{f}} \beta^{\mathrm{rff}}+v^{\mathrm{rf}}$

Here, $\quad$ Age $_{\mathbf{m}}=\left[\left(\mathrm{Age}_{\mathrm{m}}-60\right),\left(\mathrm{Age}_{\mathrm{m}}-60\right)^{2}, \ldots .,\left(\mathrm{Age}_{\mathrm{m}}-60\right)^{n}\right]$,

$$
\text { Age }_{\mathbf{f}}=\left[\left(\text { Age }_{\mathrm{f}}-60\right),\left(\text { Age }_{\mathrm{f}}-60\right)^{2}, \ldots .,\left(\mathrm{Age}_{\mathrm{f}}-60\right)^{n}\right]
$$

The vectors $Z_{\mathbf{m}}$ and $Z_{\mathbf{f}}$ contain control variables (other than age functions) such as education level, presence of children, area of residence dummies, and a dummy for whether the time use diary was collected on a weekend day. $D_{\mathrm{m}}$ and $D_{\mathrm{f}}$ are dummies for whether the male and female partners have reached age 60 (720 months of age); Greek letters denote (vectors of) coefficients. The $v$ s are normally distributed error terms, independent of $\boldsymbol{Z}_{\mathbf{m}}$ and $\boldsymbol{Z}_{\mathrm{f}}$ and the ages of both partners but allowed to be correlated across equations. The five equations are estimated jointly using maximum likelihood with heteroskedasticity robust standard errors (see Roodman 2007, 2009). By allowing the error terms in Eqs. (1)-(5) to be correlated in an arbitrary way, own and partner's retirement is allowed to be endogenous to the amounts of leisure time. We estimate this model using four alternative definitions of leisure hours together $L_{\mathrm{h}}$ and separate leisure hours of the husband $\left(L_{\mathrm{m}}\right)$ and wife $\left(L_{\mathrm{f}}\right)$; see Section $3 .^{7}$ If leisure complementarities in retirement are important, we would expect to find an immediate and positive effect of retirement on partners' leisure time together.

Because in about a third of the sample the woman was a "housewife" (see below Section 3, for a discussion), we also re-estimate the model dropping couples in which the wife was a "housewife." Finally, to set all this into perspective, to gather some information on the relative size of the changes in leisure upon retirement, relative to other time allocation choices, we also estimate a similar model for housework, specifying a four-equation system for each partner's retirement and each partner's housework time. A large increase in the husband's housework upon the husband's retirement is documented for the USA (Aguiar and Hurst 2005) and France (Stancanelli and Van Soest 2012). As far as joint household work goes, only $25 \%$ of the couples in the sample are found to perform any housework together and we find no significant effect of retirement on joint housework (results available from the authors). 


\section{The data: sample selection and covariates}

The data for the analysis are drawn from the 1998-1999 French time use survey, carried out by the French National Statistical Offices (INSEE). ${ }^{8}$ This survey is a representative sample of more than 8000 French households. Three questionnaires were collected: a household questionnaire, an individual questionnaire, and a diary of activities. The response rate to the survey was $80 \%$ (Lesnard 2009). The diary was collected for both adults in the household on the same day, which was chosen by the survey designers and could be either a weekday or a weekend day. Activities were coded in 10-min slots.

\subsection{Sample selection}

We selected married and unmarried couples and dropped one same-sex couple, giving us a sample of 5287 couples of all ages. We then applied the following criteria to select our estimation sample:

1. Each partner was aged 50 to 70 -which reduced the sample size to 1395 couples.

2. Each partner had filled in the diary (1286 couples).

3. No partner had filled in the diary on an atypical day, defined as a special occasion day, a vacation day, a wedding or a funeral, or a sickness day (1180 couples).

4. We dropped five couples where the partners did not fill in the activity diary on the same day.

5. We dropped couples with severely health-handicapped partners (60 couples).

6. We dropped couples where the male partner was unemployed or inactive (72 couples).

7. We kept housewives and unemployed women (as the borderline between the two states is not always clear-cut and especially so for older women).

Applying these criteria led to a sample of 1043 couples. We kept in the sample housewives or other inactive women. We check the sensitivity of the results to excluding housewives or other inactive women other than retirees from the sample.

\subsection{Leisure, age, retirement, and covariates}

Our definition of leisure includes 46 activities encompassing socializing; eating out or also eating at home; doing sports; playing video games; watching television; reading; going to the cinema, the theater, or arts exhibitions; hiking; walking; fishing; hunting; performing religious practices; and relaxing. This corresponds to what Aguiar and Hurst (2007) and others define as "narrow" leisure. Broader measures include any time not at work, including housework and sleep. We do not consider housework as leisure (since it is not seen as enjoyable by many) but estimate a comparable model of the effect of retirement on housework of both partners. We also do not include sleep in leisure as it is closer to "biological" time than to leisure. Our aim is to capture complementarities in leisure, and therefore, we focus on activities that are considered as "pure" leisure, that is, enjoyable time.

Based upon the information in the activity diary, we use the following four different definitions of joint leisure hours' 
a) Both partners reported exactly the same type of leisure activity (out of the 46 considered) during the same 10-min slot, and both of them also said that they did this activity "with family" (the question "with whom" allows for four possible answers: family, friends, neighbors, or other people).

b) Both partners reported exactly the same type of leisure activity (out of the 46 considered) during the same 10-min slot and reported performing this at the same place (there are four possible locations defined for each activity in the diary: at home, at work, outside, or somewhere else).

c) Both partners reported exactly the same type of leisure activity (out of the 46 considered) during the same 10-min slot.

d) Both partners reported any of the leisure activities (any of the possible 46 listed) during the same 10-min slot and reported performing this at the same place.

The four definitions are ordered from narrow to rather broad. Definition a can be seen as the narrowest and comes closest to leisure hours spent "truly together." Definition b is broader as it encompasses situations in which, for example, both partners are at home and reading at the same time. Definition c also counts as joint leisure, for example, diary episodes during which both partners are reading but not at the same place. Definition $d$ is the broadest of all, as it also considers as joint leisure, for example, the case where the husband watches TV and the wife reads a book and they are both at home. The leisure episodes of each partner that are not classified as "joint leisure" are considered as separate leisure, implying that we also have four different definitions of separate leisure hours of each partner.

To investigate how partners spend the time freed up by retirement if they do not spend it on leisure, we also construct measures of housework and time spent caring for others. Housework includes the following activities (see Stancanelli and Van Soest 2012): cleaning, doing the laundry, ironing, cleaning the dishes, setting the table, doing administrative paper work for the household, shopping, cooking, gardening, house repairs, knitting, sewing, making jam, and taking care of pets. Care hours include time spent caring for children or for other adults. Furthermore, we also investigated whether partners carry out household work together, using a similar approach as to construct their joint leisure hours. It turned out that only a negligible part of household work is carried together and that our main conclusions are not affected by looking at this variable (results are available from the authors).

The employment or retirement status in our analysis is derived from the respondent's self-assessed occupational status (at the day of the interview). The indicator for retirement takes the value one for respondents that reported to be retirees or early retirees. In the analysis, inactive women will be considered as non-employed as opposed to those still at work. We are interested in leisure complementarities, and housewives have as much time available as retired women.

As far as the other covariates go, we control for education dummies, the number of children living at home, area of residence dummies, seasonal dummies, and for the day (weekday or weekend) on which the activity diary was collected. 


\subsection{Descriptive statistics}

Descriptive statistics for the estimation sample are given in Table 1 . About $57 \%$ of the men and $43 \%$ of the women in the sample are aged 60 or above. On average, the husband is about 2 years older than the wife. The percentage employed is larger for men (36 \%) than for women (32\%). ${ }^{10}$ The vast majority of men and women have less than a high school education (the benchmark). Men tend to be slightly more educated than women: 12 (10) \% of husbands (wives) have completed high school, and 15 (11) \% have at least a college education. Few couples in this age range still have children living at home, and few are cohabiting rather than married (4\%).

Participation rates and mean and median durations of all the activities as defined in the previous subsection (in minutes per day) are given in Table 2. First of all, almost all individuals in the sample participate in leisure separately and "together." About $99 \%$ participate in separate leisure activities on the diary day. Depending on the definition of joint leisure, between 94 and $98 \%$ spend some leisure together. Going from the narrowest to the broadest definition of joint leisure (see Section 3.2), joint leisure hours increase progressively, and separate leisure hours fall. Under the narrowest definition, the husband enjoys on average $5 \mathrm{~h}$ per day of separate leisure activities and the wife a little less than $4 \mathrm{~h}$, while almost $2.5 \mathrm{~h}$ are spent on leisure activities done together. Adopting the broadest definition of joint leisure, the husband spends almost 4 and the wife spends $2.5 \mathrm{~h}$ of leisure on their own, while joint leisure averages to $4 \mathrm{~h}$.

The participation rates in housework on the diary day are equal to $87 \%$ for men and $99 \%$ for women. Women perform over $5 \mathrm{~h}$ of housework per day on average, compared to about $3 \mathrm{~h}$ for men. Only $15 \%$ of the male partners in the sample and $22 \%$ of the female partners participate in caring activities for children or adults. The average time (including the numerous zeroes) devoted to caring for others on a representative day amounts to $18 \mathrm{~min}$ for men and $24 \mathrm{~min}$ for women.

Table 1 Descriptive statistics

\begin{tabular}{|c|c|c|c|c|}
\hline & \multicolumn{2}{|c|}{ Male partner } & \multicolumn{2}{|l|}{ Female partner } \\
\hline & Mean & Standard deviation & Mean & Standard deviation \\
\hline Age (in years) & 60.72 & 5.50 & 58.60 & 5.61 \\
\hline Age 60 or older, dummy & 0.57 & 0.49 & 0.43 & 0.47 \\
\hline Retired & 0.64 & 0.48 & 0.67 & 0.47 \\
\hline Employed & 0.36 & 0.48 & 0.32 & 0.47 \\
\hline High school (12-year schooling) & 0.12 & 0.32 & 0.10 & 0.30 \\
\hline \multirow[t]{3}{*}{ College and more } & 0.15 & 0.36 & 0.11 & 0.31 \\
\hline & & \multicolumn{3}{|c|}{ Household characteristics } \\
\hline & & Mean & \multicolumn{2}{|l|}{ Standard deviation } \\
\hline Number of children at home & & 0.15 & \multicolumn{2}{|l|}{0.51} \\
\hline Cohabiting & & 0.04 & \multicolumn{2}{|l|}{0.19} \\
\hline Weekend diary & & 0.23 & \multicolumn{2}{|l|}{0.42} \\
\hline Winter season diary & & 0.25 & \multicolumn{2}{|l|}{0.42} \\
\hline Observations & & 1043 & & \\
\hline
\end{tabular}

Note: Source: French Time Use Survey 1998-1999; couples with both partners of age 50-70. See Section 3 for variable definitions and sample selection steps 
Table 2 Participation rates and mean durations (in minutes per day) in leisure and work activities

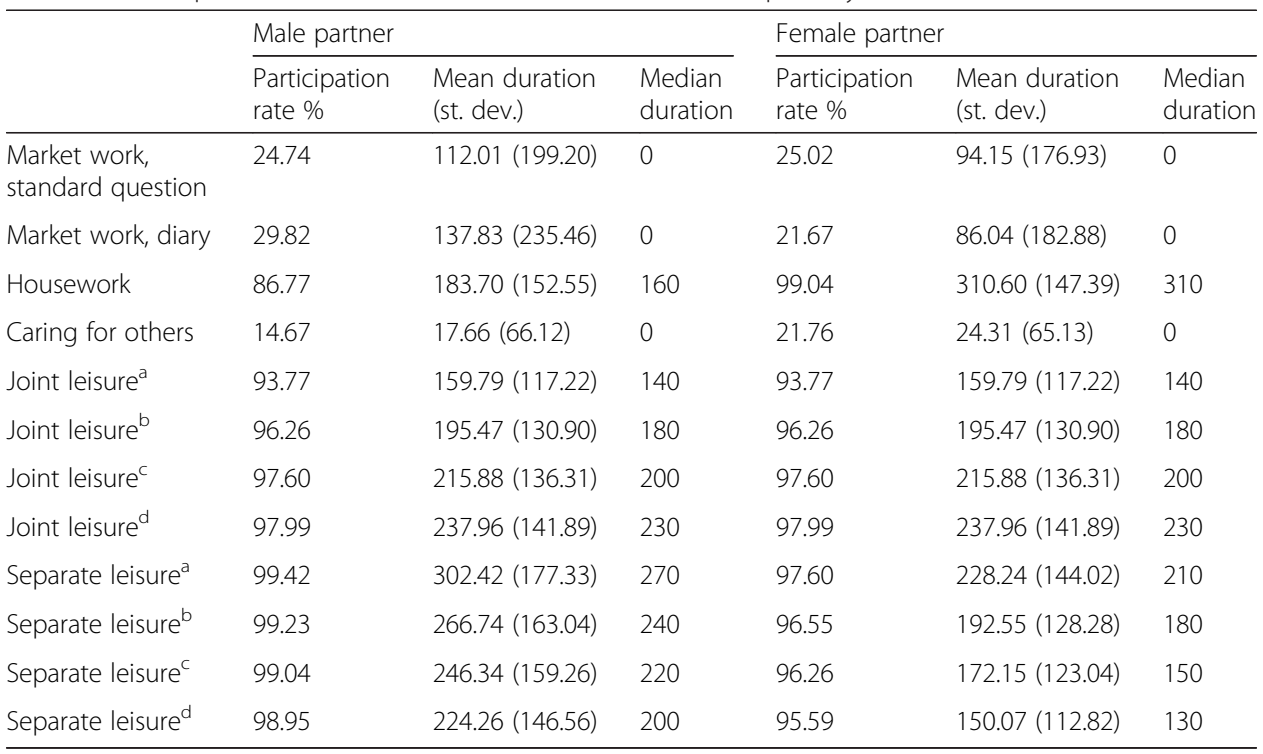

Note: Source: see Table 1. Activities measured in minutes per day. Definitions a-d of joint leisure are given in Section 3.2 aExactly the same leisure activity carried out by the partners at the same time of the diary day and with "family"

${ }^{b}$ Exactly the same leisure activity carried out by the partners at the same time and at the same place

'Exactly the same leisure activity carried out by the partners at the same time

${ }^{d}$ Any leisure activity carried out by the partners at the same time and at the same place

\section{Estimation results}

As discussed in Section 2, we estimate the effect of partners' retirement on leisure hours spent separately and together, instrumenting partners' retirement with dummies for reaching the legal retirement age ("age $\geq 60$ dummies") for each partner. In particular, we use a simultaneous-equation approach and estimate a five-equation model of partners' retirement and partners' leisure demands by simulated maximum likelihood. We present the results both including and excluding other covariates. We also check the sensitivity of the results to dropping couples in which the wife was a "housewife," thus only selecting dual earners before and after retirement. Finally, using a foursimultaneous-equation model (two equations for partners' retirement and two for partners' housework), we investigate the effect of partners' retirement on housework and time devoted to caring for other adults and children-to relativize the size of changes in different activities upon retirement. Various other specification checks were performed (and are available from the authors upon request), and our main conclusions were not affected.

Table 3 presents the estimation results assuming that retirement is exogenous to the demand for leisure and controlling for the same explanatory variables as in our preferred specification, specifying each equation as a single equation model. Under this setup, we find that for all four definitions of joint leisure, joint leisure increases strongly upon each partner's retirement. In particular, partners' leisure time together goes up by between 65 and 95 min per day upon retirement of the husband and by 35 to 49 min when the wife retires. The amount of leisure time that the husband spends on his own also increases strongly upon his retirement, by 99 to $129 \mathrm{~min}$ per day, and falls by roughly 14 to $27 \mathrm{~min}$ upon retirement of the wife, though the latter effect is only weakly significant. The wife's separate leisure time increases significantly upon her own 
Table 3 The effect of retirement on joint and separate leisure: single-equation estimates, assuming that retirement is exogenous

\begin{tabular}{llll}
\hline & \multicolumn{2}{l}{ Outcome definition a, same leisure activity, same time interval, with family } \\
\hline & His separate leisure & Her separate leisure & Joint leisure \\
He retired & $115.749^{* * *}$ & $-24.91^{*}$ & $78.40^{* * *}$ \\
& $(17.454)$ & $(13.63)$ & $(13.45)$ \\
She retired & $-21.505^{*}$ & $60.98^{* *}$ & $43.77^{* * *}$ \\
& $(12.444)$ & $(9.72)$ & $(9.59)$ \\
Mean leisure (at age 55-59) & 268.9 & 209.36 & 138
\end{tabular}

Outcome definition b, same leisure activity, same time interval, same place

His separate leisure Her separate leisure Joint leisure

$\begin{array}{llll}\text { He retired } & 129.02^{* * *} & -11.4 & 64.88^{* * *} \\ & (18.609) & (15.81) & (12.36) \\ \text { She retired } & -13.93 & 68.99^{* *} & 35.756^{* * *} \\ & (13.27) & (11.27) & (8.816) \\ \text { Mean leisure (at age 55-59) } & 241.28 & 181.74 & 165.78\end{array}$

Outcome definition c, same leisure activity, same time interval

His separate leisure Her separate leisure Joint leisure

$\begin{array}{llll}\text { He retired } & 115.749^{* * *} & -24.639^{*} & 78.214^{* * *} \\ \text { She retired } & (17.454) & (14.158) & (13.296) \\ & -21.505^{*} & 61.427^{* * *} & 43.324^{* * *} \\ & (12.444) & (10.095) & (9.480) \\ 224.22 & 164.68 & 182.84\end{array}$

Outcome definition d, any leisure activity, same time interval, same place His separate leisure Her separate leisure Joint leisure

$\begin{array}{llll}\text { He retired } & 99.20^{* * *} & -41.29^{* * *} & 94.76^{* * *} \\ & (15.27) & (12.34) & (13.689) \\ \text { She retired } & -27.40^{* *} & 55.53^{* * *} & 49.217^{* * *} \\ & (11.39) & (8.80) & (9.760) \\ \text { Mean leisure (at age 55-59) } & 207.61 & 148.07 & 199.45\end{array}$

Notes: Other controls: quadratic polynomials in age 60 interacted with the age $\geq 60$ dummies; partners' education dummies; a dummy for any child still living at home; area of residence dummies; seasonal dummies; and a weekend diary dummy. See Section 2 for the model specification and Section 3.2 for the definitions of leisure. Here, retirement of the wife is defined as non-employment. Observations: 1043 couples both aged $50-70$

${ }^{*} p<0.1 ;{ }^{* *} p<0.05 ;{ }^{* * *} p<0.01$. Standard errors in parentheses

retirement by 56 to $69 \mathrm{~min}$ per day and falls by 11 to $41 \mathrm{~min}$ upon the husband's retirement, though the latter effect is not statistically significant in some of the specifications.

Tables 4 (excluding other covariates) and 5 (including other covariates) show that these patterns are quite different when we allow for the endogeneity of the retirement decisions. Each block in Table 4 presents the selected estimates from the five-equation model-which includes two retirement equations, one equation for joint leisure, and two for separate leisure (see Section 2), for each of the four definitions of joint and separate leisure (see Section 3). The "first-stage" estimates (the effect of each spouse turning 60 on each spouse's retirement equation) are shown for simplicity only once, in the 
Table 4 The effect of retirement on joint and separate leisure: simultaneous-equation estimates, instrumenting retirement of both partners with the age $\geq 60$ dummies; no other controls except age functions

\begin{tabular}{lll}
\hline & His retirement & Her retirement \\
His age 60 and above & $0.380^{* * *}$ & $0.157^{* *}$ \\
& $(0.035)$ & $(0.051)$ \\
Her age 60 and above & 0.031 & $0.187^{* * *}$ \\
& $(0.035)$ & $(0.051)$ \\
Mean retirement (age 55-59) & 0.3259 & 0.485
\end{tabular}

Outcome definition a, same leisure activity, same time interval, with family His separate leisure Her separate leisure Joint leisure

$\begin{array}{llll}\text { He retired } & 200.89^{* *} & -78.82 & -39.32 \\ & (85.92) & (85.03) & (57.62) \\ \text { She retired } & -94.66 & 300.40^{* *} & 95.17 \\ & (128.94) & (127.65) & (86.47) \\ \text { Mean leisure (at age 55-59) } & 268.9 & 209.36 & 138\end{array}$

Outcome definition b, same leisure activity, same time interval, same place His separate leisure Her separate leisure Joint leisure

$\begin{array}{llll}\text { He retired } & 213.95^{* *} & -65.65 & -52.37 \\ & (82.80) & (73.57) & (65.19 \\ \text { She retired } & -149.27 & 245.59^{* *} & 149.79 \\ & (124.23) & (110.42) & (97.83) \\ \text { Mean leisure (at age 55-59) } & 241.28 & 181.74 & 165.78\end{array}$

Outcome definition c, same leisure activity, same time interval His separate leisure Her separate leisure Joint leisure

$\begin{array}{llll}\text { He retired } & 188.80^{* *} & -90.85 & -27.22 \\ & (80.29) & (72.23) & (66.48) \\ \text { She retired } & -140.50 & 254.46^{* *} & 141.00 \\ & (120.50) & (108.41) & (99.79) \\ \text { Mean leisure (at age 55-59) } & 224.22 & 164.68 & 182.84\end{array}$

Outcome definition d, any leisure activity, same time interval, same place

$\begin{array}{llll} & \text { His separate leisure } & \text { Her separate leisure } & \text { Joint leisure } \\ \text { He retired } & 225.13^{* *} & -54.51 & -63.56 \\ & (81.40 & (60.17) & (74.47) \\ \text { She retired } & -218.46^{*} & 176.47^{* *} & 218.98^{* *} \\ & (122.16) & (90.30) & (111.78) \\ \text { Mean leisure (at age 55-59) } & 207.61 & 148.07 & 199.45\end{array}$

Notes: The table only shows the estimates of the effects of the age $\geq 60$ dummies for each partner on the retirement probabilities and the effects of each partner's retirement on joint and separate leisure (outcome equations). Other controls: quadratic polynomials in age 60 interacted with the age $\geq 60$ dummies. See Section 2 for the model specification and Section 3.2 for the definitions of leisure. Here, retirement of the wife is defined as non-employment Observations: 1043 couples aged $50-70$

${ }^{*} p<0.1 ;{ }^{* *} p<0.05 ;{ }^{* * *} p<0.01$. Standard errors in parentheses 
Table 5 The effect of retirement on joint and separate leisure: simultaneous-equation estimates, instrumenting retirement of both partners with the age $\geq 60$ dummies; with additional controls

\begin{tabular}{|c|c|c|c|}
\hline & His retirement & \multicolumn{2}{|l|}{ Her retirement } \\
\hline \multirow[t]{2}{*}{ His age 60 and above } & $0.380^{* * *}$ & \multicolumn{2}{|l|}{$0.160^{* * *}$} \\
\hline & $(0.034)$ & \multicolumn{2}{|l|}{$(0.050)$} \\
\hline \multirow[t]{2}{*}{ Her age 60 and above } & 0.035 & \multicolumn{2}{|l|}{$0.185^{* * *}$} \\
\hline & $(0.035)$ & \multicolumn{2}{|l|}{$(0.051)$} \\
\hline \multirow[t]{3}{*}{ Mean retirement (age 55-59) } & 0.3259 & \multicolumn{2}{|l|}{0.485} \\
\hline & \multicolumn{3}{|c|}{ Outcome definition a, same leisure activity, same time interval, with family } \\
\hline & His separate leisure & Her separate leisure & Joint leisure \\
\hline \multirow[t]{2}{*}{ He retired } & $165.85^{* *}$ & -100.58 & -39.46 \\
\hline & $(84.51)$ & $(94.68)$ & $(58.77)$ \\
\hline \multirow[t]{2}{*}{ She retired } & -6.27 & $375.72^{* *}$ & 94.20 \\
\hline & $(127.53)$ & $(142.88)$ & $(88.69)$ \\
\hline \multirow[t]{3}{*}{ Mean leisure (at age $55-59$ ) } & 268.9 & 209.36 & 138 \\
\hline & \multicolumn{3}{|c|}{ Outcome definition b, same leisure activity, same time interval, same place } \\
\hline & His separate leisure & Her separate leisure & Joint leisure \\
\hline \multirow[t]{2}{*}{ He retired } & $184.703^{* *}$ & -81.73 & -34.52 \\
\hline & $(80.088)$ & $(81.87)$ & $(67.43)$ \\
\hline \multirow[t]{2}{*}{ She retired } & -67.99 & $314.00^{* *}$ & $174.06^{*}$ \\
\hline & $(120.85)$ & $(123.55)$ & $(101.72)$ \\
\hline \multirow[t]{3}{*}{ Mean leisure (at age 55-59) } & 241.28 & 181.74 & 165.78 \\
\hline & \multicolumn{3}{|c|}{ Outcome definition c, same leisure activity, same time interval } \\
\hline & His separate leisure & Her separate leisure & Joint leisure \\
\hline \multirow[t]{2}{*}{ He retired } & $160.91^{* *}$ & -105.51 & -34.52 \\
\hline & $(79.09)$ & $(77.90)$ & $(67.43)$ \\
\hline \multirow[t]{2}{*}{ She retired } & -86.119 & $295.84^{* *}$ & $174.06^{*}$ \\
\hline & $(119.34)$ & $(117.56)$ & $(101.72)$ \\
\hline \multirow[t]{3}{*}{ Mean leisure (at age $55-59$ ) } & 224.22 & 164.68 & 182.84 \\
\hline & \multicolumn{3}{|c|}{ Outcome definition d, any leisure activity, same time interval, same place } \\
\hline & His separate leisure & Her separate leisure & Joint leisure \\
\hline \multirow[t]{2}{*}{ He retired } & $198.63^{* *}$ & -67.80 & -72.24 \\
\hline & $(78.24)$ & $(64.57)$ & (76.63) \\
\hline \multirow[t]{2}{*}{ She retired } & -166.41 & $215.58^{* *}$ & $254.34^{* *}$ \\
\hline & (118.06) & (97.43) & (115.63) \\
\hline Mean leisure (at age 55-59) & 207.61 & 148.07 & 199.45 \\
\hline
\end{tabular}

Notes: The table only shows the estimates of the effects of the age $\geq 60$ dummies for each partner on the retirement probabilities and the effects of each partner's retirement on joint and separate leisure (outcome equations). Other controls: quadratic polynomials in age 60 interacted with the age $\geq 60$ dummies; partners' education dummies; a dummy for any child still living at home; area of residence dummies; seasonal dummies; and a weekend diary dummy. See Section 2 for the model specification and Section 3.2 for the definitions of leisure. Here, retirement of the wife is defined as non-employment. Observations: 1043 couples aged 50-70 ${ }^{*} p<0.1 ;{ }^{* *} p<0.05 ;{ }^{* * *} p<0.01$. Standard errors in parentheses

first block, as they do not vary across the four models corresponding to the four definitions of leisure. We find that retirement increases strongly for spouses of 60 years of age: the husband's retirement probability increases by 0.38 when he is aged 60 while the wife's retirement probability increases by 0.18 when she is aged 60 . Moreover, the husband being aged at least 60 years has a positive and significant effect on the wife's 
retirement probability of about 0.16 , while the cross-effect of the wife's being aged 60 on the husband's retirement probability is positive but small and insignificant. Each of the other four blocks presents the estimated causal effect of each partner's retirement on the separate and joint leisure demands, for each definition of joint and separate leisure.

The effect of the own retirement on the separate leisure demand of each partner is statistically significant—and, for all four definitions, much larger in size than in Table 3 (where retirement was assumed to be exogenous and thus not instrumented). The amount of leisure that the husband spends on his own increases upon his retirement by roughly $3 \mathrm{~h}$ and $20 \mathrm{~min}$ per day, while the separate leisure hours of the wife go up by between 3 and $5 \mathrm{~h}$ per day upon her retirement-depending on which definition we use. These are very sizable increases, of the same order of magnitude as the average separate leisure hours of individuals aged 55 to less 60 (close to the age discontinuity), and therefore imply that separate leisure hours double upon own retirement. In contrast, most of the cross-effects of the partner's retirement on own (separate) leisure hours are insignificant-an exception is the effect of the wife's retirement on the husband's separate leisure which is significant and negative under the last definition of separate leisure (definition d).

The effect of partners' retirement on joint leisure hours is insignificant except for the broadest definition of joint leisure (definition d) for which the wife's retirement increases joint leisure by almost 220 min per day. The effect of retirement of the wife on joint leisure is positive for all definitions of joint leisure though only significant for the broadest definition adopted, but the effect of the husband's retirement is always insignificantly negative.

Table 9 in the Appendix reports the correlations of the errors of the five equations. The correlation between the errors in both partners' retirement equations is significantly positive (as expected from the joint retirement literature and it may also capture positive assortative mating) and equal to almost 0.13 . The error term in the husband's retirement equation also correlates significantly with the error in the equation for joint leisure, with an estimated correlation of about 0.20 to 0.26 , depending on the definition of joint leisure adopted. This confirms that retirement should be treated as endogenous, supporting our simultaneous-equation framework. The error term in the wife's retirement equation correlates negatively with the error term in the equation of her separate leisure. The same correlation is also negative for the husband but statistically insignificant.

Table 5 presents the same key estimates for a model that includes the additional controls $Z_{\mathbf{m}}$ and $Z_{\mathbf{f}}$ (education, children, weekday, or weekend diary; see Section 3). The estimated effects of being aged 60 on the probability to be retired are unaffected, and the estimated effects of retirement on each type of leisure remain similar. In particular, the effect of the own retirement on the own separate leisure demand remains positive and statistically significant, for all leisure definitions, though it becomes slightly smaller in size for the husband and larger for the wife. The effect of the wife's retirement on joint leisure also increases in size and is now statistically significant for definitions b and c, while it remains significant for definition $d$ and insignificantly negative for definition a.

As explained in Sections 2 and 3, our sample includes couples in which the wife reports to be a "housewife." We also estimated the model dropping these couples from the sample, with and without other explanatory variables; see Tables 6 and 7 for the 
Table 6 The effect of retirement on joint and separate leisure: simultaneous-equation estimates, instrumenting retirement of both partners with the age $\geq 60$ dummies; no other controls except age functions. Sample excluding couples in which the woman is a "housewife"

\begin{tabular}{|c|c|c|c|}
\hline & His retirement & \multicolumn{2}{|l|}{ Her retirement } \\
\hline \multirow[t]{2}{*}{ His age 60 and above } & $0.347^{* * *}$ & \multicolumn{2}{|l|}{$0.160^{* * *}$} \\
\hline & $(0.042)$ & \multicolumn{2}{|l|}{$(0.052)$} \\
\hline \multirow[t]{2}{*}{ Her age 60 and above } & $0.081^{* *}$ & \multicolumn{2}{|l|}{$0.338^{* * *}$} \\
\hline & $(0.042)$ & \multicolumn{2}{|l|}{$(0.052)$} \\
\hline \multirow[t]{3}{*}{ Mean retirement (age 55-59) } & 0.353 & \multicolumn{2}{|l|}{0.221} \\
\hline & \multicolumn{3}{|c|}{ Outcome definition a, same leisure activity, same time interval, with family } \\
\hline & His separate leisure & Her separate leisure & Joint leisure \\
\hline \multirow[t]{2}{*}{ He retired } & $205.65^{* *}$ & -65.78 & -73.93 \\
\hline & $(100.59)$ & $(86.05)$ & $(67.04)$ \\
\hline \multirow[t]{2}{*}{ She retired } & -147.51 & $178.89^{* *}$ & $118.77^{*}$ \\
\hline & $(94.62)$ & $(80.95)$ & $(63.07)$ \\
\hline \multirow[t]{3}{*}{ Mean leisure (at age 55-59) } & 274.71 & 197.05 & 142.94 \\
\hline & \multicolumn{3}{|c|}{ Outcome definition b, same leisure activity, same time interval, same place } \\
\hline & His separate leisure & Her separate leisure & Joint leisure \\
\hline \multirow[t]{2}{*}{ He retired } & $242.68^{* *}$ & -28.76 & -110.96 \\
\hline & $(94.52)$ & (78.03) & $(74.59)$ \\
\hline \multirow[t]{2}{*}{ She retired } & $-165.21^{*}$ & $161.19^{* *}$ & $136.47^{*}$ \\
\hline & $(88.92)$ & $(73.40)$ & $(70.17)$ \\
\hline \multirow[t]{3}{*}{ Mean leisure (at age 55-59) } & 227.5 & 150.29 & 190.15 \\
\hline & \multicolumn{3}{|c|}{ Outcome definition c, same leisure activity, same time interval } \\
\hline & His separate leisure & Her separate leisure & Joint leisure \\
\hline \multirow[t]{2}{*}{ He retired } & $221.66^{* *}$ & -49.77 & -89.94 \\
\hline & $(93.03)$ & $(74.73)$ & $(76.52)$ \\
\hline \multirow[t]{2}{*}{ She retired } & $-169.65^{* *}$ & $156.75^{* *}$ & $140.91^{* *}$ \\
\hline & $(87.52)$ & $(70.30)$ & $(71.98)$ \\
\hline \multirow[t]{3}{*}{ Mean leisure (at age 55-59) } & 243.97 & 166.76 & 173.68 \\
\hline & \multicolumn{3}{|c|}{ Outcome definition d, any leisure activity, same time interval, same place } \\
\hline & His separate leisure & Her separate leisure & Joint leisure \\
\hline \multirow[t]{2}{*}{ He retired } & $252.10^{* *}$ & -19.35 & -120.37 \\
\hline & $(90.09)$ & $(65.99)$ & $(81.60)$ \\
\hline \multirow[t]{2}{*}{ She retired } & $-217.71^{* *}$ & $108.69^{*}$ & $188.98^{* *}$ \\
\hline & $(84.75)$ & $(62.08)$ & $(76.77)$ \\
\hline Mean leisure (at age 55-59) & 206.76 & 129.56 & 210.88 \\
\hline
\end{tabular}

results. In this sample of 732 couples, not only the estimates of the jumps in retirement for those that are 60 years of age are still strongly significant and robust but also the cross-effect of the wife's age $\geq 60$ dummy on the husband's retirement becomes large and significant (equal to almost 0.1). The effects of the husband's retirement on his separate leisure demand and of the wife's retirement on her separate leisure remain large and significantly positive (both including and excluding other covariates). The effect of the wife's retirement on joint leisure time is always positive and significant. Moreover, retirement of the husband does not affect joint leisure under any of these specifications, 
Table 7 The effect of retirement on joint and separate leisure: simultaneous-equation estimates, instrumenting retirement of both partners with the age $\geq 60$ dummies; with additional controls. Sample excluding couples in which the woman is a "housewife"

\begin{tabular}{|c|c|c|c|}
\hline & His retirement & \multicolumn{2}{|l|}{ Her retirement } \\
\hline \multirow[t]{2}{*}{ His age 60 and above } & $0.342^{* * *}$ & \multicolumn{2}{|l|}{$0.151^{* * *}$} \\
\hline & $(0.041)$ & \multicolumn{2}{|l|}{$(0.050)$} \\
\hline \multirow[t]{2}{*}{ Her age 60 and above } & $0.097^{* *}$ & \multicolumn{2}{|l|}{$0.339^{* * *}$} \\
\hline & $(0.041)$ & \multicolumn{2}{|l|}{$(0.051)$} \\
\hline \multirow[t]{3}{*}{ Mean retirement (age 55-59) } & 0.353 & \multicolumn{2}{|l|}{0.221} \\
\hline & \multicolumn{3}{|c|}{ Outcome definition a, same leisure activity, same time interval, with family } \\
\hline & His separate leisure & Her separate leisure & Joint leisure \\
\hline \multirow[t]{2}{*}{ He retired } & $161.84^{*}$ & -101.66 & -54.27 \\
\hline & $(98.27)$ & $(90.63)$ & $(66.09)$ \\
\hline \multirow[t]{2}{*}{ She retired } & -86.69 & $251.56^{* *}$ & $117.49^{*}$ \\
\hline & $(94.66)$ & $(87.30)$ & $(63.66)$ \\
\hline \multirow[t]{3}{*}{ Mean leisure (at age 55-59) } & 274.71 & 197.05 & 142.94 \\
\hline & \multicolumn{3}{|c|}{ Outcome definition b, same leisure activity, same time interval, same place } \\
\hline & His separate leisure & Her separate leisure & Joint leisure \\
\hline \multirow[t]{2}{*}{ He retired } & $208.34^{* *}$ & -55.18 & -100.75 \\
\hline & $(92.27)$ & $(8238)$ & $(73.67)$ \\
\hline \multirow[t]{2}{*}{ She retired } & -108.96 & $229.29^{* *}$ & $139.77^{* *}$ \\
\hline & $(88.88)$ & $(79.35)$ & $(70.96)$ \\
\hline \multirow[t]{3}{*}{ Mean leisure (at age $55-59$ ) } & 227.5 & 150.29 & 190.15 \\
\hline & \multicolumn{3}{|c|}{ Outcome definition c, same leisure activity, same time interval } \\
\hline & His separate leisure & Her separate leisure & Joint leisure \\
\hline \multirow[t]{2}{*}{ He retired } & $188.48^{* *}$ & -75.04 & -80.90 \\
\hline & $(92.03)$ & (78.59) & $(74.01)$ \\
\hline \multirow[t]{2}{*}{ She retired } & -127.30 & $210.95^{* *}$ & $158.10^{* *}$ \\
\hline & $(88.65)$ & $(75.70)$ & $(71.30)$ \\
\hline \multirow[t]{3}{*}{ Mean leisure (at age 55-59) } & 243.97 & 166.76 & 173.68 \\
\hline & \multicolumn{3}{|c|}{ Outcome definition d, any leisure activity, same time interval, same place } \\
\hline & His separate leisure & Her separate leisure & Joint leisure \\
\hline \multirow[t]{2}{*}{ He retired } & $228.84^{* *}$ & -34.70 & -121.26 \\
\hline & $(88.67)$ & $(68.62)$ & $(80.26)$ \\
\hline \multirow[t]{2}{*}{ She retired } & $-187.37^{* *}$ & $150.90^{* *}$ & $218.18^{* *}$ \\
\hline & $(85.61)$ & $(66.10)$ & $(77.31)$ \\
\hline Mean leisure (at age 55-59) & 206.76 & 129.56 & 210.88 \\
\hline
\end{tabular}

Notes: The table only shows the estimates of the effects of the age $\geq 60$ dummies for each partner on the retirement probabilities and the effects of each partner's retirement on joint and separate leisure (outcome equations). Other controls: quadratic polynomials in age 60 interacted with the age $\geq 60$ dummies; partners' education dummies; a dummy for any child still living at home; area of residence dummies; seasonal dummies; and a weekend diary dummy. See Section 2 for the model specification and Section 3.2 for the definitions of leisure. Observations: 732 couples aged 50-70 ${ }^{*} p<0.1 ;{ }^{* *} p<0.05 ;{ }^{* *} p<0.01$. Standard errors in parentheses

and its sign is negative as before. In addition, the effect of the wife's retirement on the husband's separate leisure, which is negative in all specifications, now becomes statistically significant for some of the leisure definitions.

All in all, controlling for the endogeneity of retirement, the finding that separate leisure time of the husband increases dramatically upon his retirement is very robust. 
The wife's separate leisure demand also increases significantly and dramatically upon her retirement, but this effect is somewhat less robust to changes in the sample or the specification. Partners' joint leisure time increases upon retirement of the wife (who is often the last to retire among dual earners) or upon retirement of the husband in couples in which she is a housewife. The significance and the size of the increase in joint leisure upon the wife's retirement are, however, sensitive to the sample cut and the inclusion or exclusion of other covariates.

To gather more insight into how time allocation changes upon retirement, we use the same type of model to investigate changes in household work and time spent caring for others. The results for the main sample are summarized in Table 8. The results for household work are similar to those in Stancanelli and Van Soest (2012). The husband's retirement leads to a dramatic increase in the time he devotes to housework of about 280 min per day (while the average husband aged 55-59 spends only 130 to $140 \mathrm{~min}$ per day on housework). This is also in line with earlier findings for the USA (Aguiar and Hurst 2005). This increase is partly undone if the wife also retires, which leads to an estimated reduction of $190 \mathrm{~min}$, though this estimate is very imprecise and not statistically significant. The care time of the husband also increases significantly upon his retirement, by about $70 \mathrm{~min}$, while the average husband aged 55-59 spends only 10 to 12 min per day on caring for others. Household work and care time of the wife do not

Table 8 Results of estimation of the effect of partners' retirement on household work. Simultaneous-equation estimation. Full sample of couples. Instrumenting retirement with the dummy for being aged 60 and above and including other covariates

\begin{tabular}{|c|c|c|}
\hline & His retirement & Her retirement \\
\hline \multirow[t]{2}{*}{ His age 60 and above } & $0.380^{* * *}$ & $0.160^{* * *}$ \\
\hline & $(0.034)$ & $(0.050)$ \\
\hline \multirow[t]{2}{*}{ His age 60 and above } & 0.035 & $0.185^{* * *}$ \\
\hline & $(0.035)$ & $(0.051)$ \\
\hline \multirow[t]{3}{*}{ Mean retirement (age 55-59) } & 0.359 & 0.485 \\
\hline & Housework (minute & \\
\hline & His housework & Her housework \\
\hline \multirow[t]{2}{*}{ He retired } & $276.435^{* *}$ & 69.248 \\
\hline & $(80.60)$ & (75.524) \\
\hline \multirow[t]{2}{*}{ She retired } & -189.040 & -21.775 \\
\hline & $(121.62)$ & $(113.96)$ \\
\hline \multirow[t]{3}{*}{ Mean housework (at age 55-59) } & 143.398 & 291.65 \\
\hline & Care for children ar & ner households (minutes per day) \\
\hline & His care for others & Her care for others \\
\hline \multirow[t]{2}{*}{ He retired } & $69.15^{* *}$ & 58.209 \\
\hline & $(34.65)$ & $(36.92)$ \\
\hline \multirow[t]{2}{*}{ She retired } & -0.043 & -50.889 \\
\hline & $(52.28)$ & $(55.692)$ \\
\hline Mean care for others (at age 55-59) & 11.94 & 29.13 \\
\hline
\end{tabular}

We only show results of estimation of the effects of the dummies for being age 60 and above of each partner on the retirement probability (first stage) and the effect of each partner's retirement on the outcome equations. Other controls include partners' age polynomials interacted with the dummies for being aged 60 and above; partners' education dummies; a dummy for any child still living at home; area of residence fixed effects; season of the year; and weekend diary dummies. See Section 2 for the model specification and Section 3.2 for the data definitions ${ }^{*} p<0.1 ;{ }^{* *} p<0.05 ;{ }^{* * *} p<0.01$. Standard errors in parentheses 
respond significantly to either the wife's or the husband's retirement, perhaps because the wife already devotes a considerable amount of time to housework and unpaid care for others before retirement. Considering the common case where the husband retires first, we find that if the husband retires, the time that becomes available is mostly spent on home production and separate leisure activities. When the wife also retires, these activities are partly replaced by joint leisure activities-particularly if we take a broad definition of joint leisure (same time interval, same place, but not necessarily the same activity or activities carried out together). The husband's retirement has little influence on the wife's time allocation. When she then also retires, most of the time she no longer spends on paid work goes to separate and joint leisure activities. Finally, we also experimented with constructing an alternative measure of housework performed together by the two partners, in a similar way as for leisure together. Our conclusions were not affected, and we found little increases in joint household work upon spousal retirement (results are available from the authors).

\section{Conclusions}

In the literature on partners' retirement decisions, one of the main explanations for joint retirement is leisure complementarities. This is the first study to investigate the extent to which leisure hours together of partners change upon retirement. We use diary data on leisure activities of French couples in the age group 50-70 to investigate the causal effect of both partners' retirement on the time spent on separate and joint leisure activities.

The data are drawn from a French time use survey that collected an activity diary for both partners on the same day (chosen by the interviewer) and also asked additional questions on "with whom" and "where' the activity was carried out. This allows us to construct four alternative measures of joint leisure hours. On a typical day, using the narrowest definition of joint leisure, the husband and the wife enjoy on average 5 and $4 \mathrm{~h}$ of separate leisure activities, respectively, while over $2.5 \mathrm{~h}$ are spent on leisure activities done together. Adopting the broadest definition of joint leisure, the husband and the wife spend almost 4 and $2.5 \mathrm{~h}$ of leisure on their own, respectively, while joint leisure averages to almost $4 \mathrm{~h}$.

Our identification strategy builds upon the fact that for many French workers, the legal retirement age is 60 , which enables us to take an instrumental variable approach to estimate the effect of retirement on partners' leisure hours separate or together. We specify and estimate a five-simultaneous-equation model with two retirement equations, two separate leisure equations, and an equation for joint leisure. We find a significant jump in the own retirement probability at age 60, equal to about 0.38 for the husband and 0.34 for the wife, which supports our identification strategy.

A robust finding is that the husband's retirement leads to a dramatic increase in the husband's leisure time spent separately from the wife, by more than $3 \mathrm{~h}$ per day. This may be explained by the fact that the husband is often the first to retire as he is usually older than the wife. Accordingly, we find that the husband's retirement has no effect on partners' joint leisure in any of the models accounting for the endogeneity of retirement. The wife's retirement increases her separate leisure hours by a large amount (three or more hours per day) and increases joint leisure hours. All in all, we conclude that her retirement leads to only a modest increase in partners' joint leisure hours. However, the leisure complementarity argument may hinge not only on the "quantity" but also on the "quality" of partners' leisure time together, which is something we cannot measure with the current 
data and that future studies may want to explore. We also do not know whether health was affected by retirement which may also impede on partners' allocation of time. Changes in time allocation may reflect partners' valuation of leisure together versus leisure separate, which may also vary when a substantial amount of time becomes available due to retiring from work. Our findings confirm that there are significant leisure complementarities in partners' retirement though their size is perhaps smaller than anticipated in the joint retirement literature.

\section{Endnotes}

${ }^{1}$ Pension benefits are individualized and do not increase if people continue to work past a certain age or contribution record. There is no spouse allowance in the French pension system. There are different legal age thresholds, but age 60 is one that binds the most, and indeed, most workers in France retire at 60 (OECD online data on effective retirement age in OECD countries).

${ }^{2}$ This effect is not robust to specification checks though, perhaps due to the smaller size of the sample of couples in which the wife was active.

${ }^{3}$ See, for example, Blanchet and Pele (1997) for more details of the French pension system. In 2010, the legal early retirement age was set at 62 years, but this will become effective only in 2018 (Hairault et al. 2010).

${ }^{4}$ Due to various reforms of social security, the number of years one needs to work in order to be able to retire with the maximum level of pension benefits depends on individual birthday. Once individuals turn into legal retirement age, which is 60 years for most workers, and have worked enough years to retire with the maximum level of pension benefits, their pension benefits do not increase anymore if they continue to work. This explains the large and significant jump into retirement at age 60, which indeed enables us to apply a RD framework.

${ }^{5}$ Since participation in leisure is almost $100 \%$ for either separate or joint leisure together (see Section 3), we can use a linear specification for the leisure equations.

${ }^{6} \mathrm{We}$ opt for a linear specification of the retirement equations and adjust the standard error by estimating robust standard error.

${ }^{7}$ We do not aim at modeling how retirement decisions depend upon financial incentives such as the pension system. We do not use an explicit (structural) model of household decision-making either. Therefore, we do not make assumptions on how preferences differ across the two partners or whether the outcome for the household as a whole reflects a cooperative or non-cooperative equilibrium. Though very interesting these issues are, they are certainly worth a separate treaty and far beyond the scope of our paper.

${ }^{8}$ The next French Time Use Survey 2009-2010 (the French time use survey is run every 12 years by the INSEE, the national statistical offices) has a more complex framework in which couples were asked to fill in several additional questionnaires than the diary which very unfortunately led to fewer couples filling in the time diary, and this makes the size of the sample with both partners' diaries available far too small for the purposes of our analysis.

'Barnet-Verzat et al. (2011) use similar definitions of joint leisure to study parents' leisure time in the presence of children.

${ }^{10}$ The correlation between the non-employment status (i.e. retirement) of the two partners is equal to 0.45 while that between the dummies for age 60 and above of the two partners is 0.64 . 


\section{Appendix}

Table 9 Correlations of the errors of the equations from the models in Table 4

\begin{tabular}{|c|c|c|c|c|}
\hline & \multicolumn{3}{|c|}{ Outcome definition a, same leisure activity, same time interval, with family } & \multirow[b]{2}{*}{ Joint leisure } \\
\hline & Her retirement & His separate leisure & Her separate leisure & \\
\hline \multirow[t]{2}{*}{ His retirement } & $0.127^{* * *}$ & -0.104 & 0.029 & $0.250^{* *}$ \\
\hline & $(0.031)$ & $(0.112)$ & $(0.113)$ & $(0.108)$ \\
\hline \multirow[t]{2}{*}{ Her retirement } & & 0.164 & $-0.609^{* *}$ & -0.151 \\
\hline & & $(0.285)$ & $(0.280)$ & $(0.283)$ \\
\hline \multirow[t]{2}{*}{ His separate leisure } & & & 0.274 & $-0.448^{* *}$ \\
\hline & & & $(0.199)$ & $(0.086)$ \\
\hline \multirow[t]{4}{*}{ Her separate leisure } & & & & -0.255 \\
\hline & & & & $(0.0205)$ \\
\hline & Outcome definit & b, same leisure activity, sar & ne time interval, same place & \\
\hline & Her retirement & His separate leisure & Her separate leisure & Joint leisure \\
\hline \multirow[t]{2}{*}{ His retirement } & $0.127^{* * *}$ & -0.140 & -0.002 & $0.262^{* *}$ \\
\hline & $(0.031)$ & $(0.109)$ & $(0.115)$ & $(0.103)$ \\
\hline \multirow[t]{2}{*}{ Her retirement } & & 0.282 & $-0.560^{* *}$ & -0.273 \\
\hline & & $(0.282)$ & $(0.283)$ & $(0.279)$ \\
\hline \multirow[t]{2}{*}{ His separate leisure } & & & 0.131 & $-0.451^{* *}$ \\
\hline & & & $(0.194)$ & $(0.126)$ \\
\hline \multirow[t]{4}{*}{ Her separate leisure } & & & & -0.164 \\
\hline & & & & $(0.205)$ \\
\hline & Outcome defini & n c, same leisure activity, s & ame time interval & \\
\hline & Her retirement & His separate leisure & Her separate leisure & Joint leisure \\
\hline \multirow[t]{2}{*}{ His retirement } & $0.127^{* * *}$ & -0.099 & 0.047 & $0.201^{*}$ \\
\hline & $(0.031)$ & $(0.111)$ & $(0.111)$ & $(0.107)$ \\
\hline \multirow[t]{2}{*}{ Her retirement } & & 0.275 & $-0.597^{* *}$ & -0.248 \\
\hline & & $(0.283)$ & $(0.279)$ & $(0.282)$ \\
\hline \multirow[t]{2}{*}{ His separate leisure } & & & 0.084 & $-0.429^{* * *}$ \\
\hline & & $(0.197)$ & $(0.115)$ & \\
\hline \multirow[t]{4}{*}{ Her separate leisure } & & & & -0.162 \\
\hline & & & $(0.207)$ & \\
\hline & Outcome defini & n d, any leisure activity, sa & me time interval, same place & \\
\hline & Her retirement & His separate leisure & Her separate leisure & Joint leisure \\
\hline \multirow[t]{2}{*}{ His retirement } & $0.127^{* * *}$ & -0.169 & -0.038 & $0.259^{* *}$ \\
\hline & $(0.031)$ & $(0.104)$ & $(0.118)$ & $(0.010)$ \\
\hline \multirow[t]{2}{*}{ Her retirement } & & $0.470^{*}$ & -0.431 & -0.431 \\
\hline & & $(0.276)$ & $(0.286)$ & $(0.273)$ \\
\hline \multirow[t]{2}{*}{ His separate leisure } & & & -0.045 & $-0.502^{* *}$ \\
\hline & & & $(0.188)$ & $(0.177)$ \\
\hline \multirow[t]{2}{*}{ Her separate leisure } & & & & -0.120 \\
\hline & & & $(0.204)$ & \\
\hline
\end{tabular}

${ }^{*} p<0.1 ;{ }^{* *} p<0.05 ;{ }^{* * *} p<0.01$. Standard errors in parentheses 


\section{Competing interests}

The IZA Journal of Labor Policy is committed to the IZA Guiding Principles of Research Integrity. The authors declare that they have observed these principles.

\section{Acknowledgements}

We are indebted for the helpful comments to Dominique Anxo, Miriam Beblo, Daniel Hamermesh, Juan F. Jimeno, Larry Katz, Daiji Kawaguchi, David Neumark, Nuria Rodriguez Planas, and Emiko Usui. We also thank two anonymous referees and the IZA JOLP editor for the useful suggestions. Any errors are ours.

Responsible editor: David Neumark

\section{Author details}

${ }^{1}$ Paris School of Economics, CNRS, 106 Boulevard de I'Hopital, 75013 Paris, France. ${ }^{2}$ IZA, Bonn, Germany. ${ }^{3}$ Netspar, Tilburg University, Tilburg, The Netherlands. ${ }^{4}$ RAND, Santa Monica, CA, USA. ${ }^{5}$ Econometrics Department, Tilburg University, PO Box 90153, 5000 LE Tilburg, The Netherlands.

Received: 6 July 2015 Accepted: 17 March 2016

Published online: 28 June 2016

\section{References}

Aguiar M, Hurst E (2005) Consumption versus expenditure. Journal of Political Economy 113(5):919-948

Aguiar M, Hurst E (2007) Measuring trends in leisure: the allocation of time over five decades. Quarterly Journal of Economics 122:969-1006

An MY, Christensen BJ, Gupta ND (2004) Mutivariate mixed proportional hazard modelling of the joint retirement of married couples. Journal of Applied Econometrics 19:687-704

Blanchet D, Pele L (1997) Social security and retirement in France, NBER Working Paper No. 6214

Casanova M (2010) Happy together: a structural model of couples' joint retirement choices. Mimeo, University of Los Angeles, California

Cecile B-V, Pailhé A, Solaz A (2011) Spending time together: the impact of children on couples' leisure synchronization. Review of Economics of the Household 9(4):465-486

Coile CC (2004) Retirement incentives and couples' retirement decisions. Topics in Economic Analysis \& Policy 4(1):1-28

Donni O, Moreau N (2007) Collective labor supply: a single-equation model and some evidence from French data. Journal of Human Resources 42:214-246

Gustman A, Steinmeier T (2000) Retirement in dual-career families: a structural model. Journal of Labor Economics 18(2000):503-545

Gustman A, Steinmeier T (2004) Social security, pensions and retirement behaviour within the family. Journal of Applied Econometrics 19(6):723-737

Hairault J-O, Langot F, Sopraseuth T (2010) Distance to retirement and older workers' employment: the case for delaying the retirement age. Journal of the European Economic Association 8(5):1034-1076

Hallberg D (2003) Synchronous leisure, jointness and household labor supply. Labour Economics 10:185-203

Hamermesh DS (2000) Togetherness: spouses' synchronous leisure, and the impact of children, NBER Working Papers 7455

Hamermesh DS (2002) Timing, togetherness and time windfalls. Journal of Population Economics 15:601-623

Hurd M (1990) The joint retirement decision of husbands and wives. In: Wise D (ed) Issues in the economics of aging. NBER, Cambridge, pp 231-258

Kawaguchi D, Lee J, Hamermesh DS (2013) A gift of time. Labour Economics 24:205-216

Lee J, Kawaguchi D, Hamermesh DS (2012) Aggregate impacts of a gift of time. American Economic Review 102(3):612-616

Lesnard L (2009) "La famille désarticulée: les nouvelles contraintes de l'emploi du temps", Lien Sociale

Pollak RA (2003) Gary Becker's contributions to family and household economics. Review of Economics of the Household 1(1-2):111-141

Roodman D (2007) CMP: Stata module to implement conditional (recursive) mixed process estimator., Statistical Software Components S456882, Boston College Department of Economics, revised 22 May 2009

Roodman D (2009) Estimating fully observed recursive mixed-process models with CMP, Working Paper 168, Center for Global Development

Stancanelli EGF, Van Soest A (2012) Retirement and home production: a regression discontinuity approach. American Economic Review, Papers and Proceedings 102:600-606

\section{Submit your manuscript to a SpringerOpen ${ }^{\circ}$ journal and benefit from:}

- Convenient online submission

- Rigorous peer review

- Immediate publication on acceptance

- Open access: articles freely available online

- High visibility within the field

Retaining the copyright to your article 